\title{
Comparison Growing Stock, Carbon Stock and Biodiversity in and Around Banke National Park, Nepal
}

\author{
Ganesh Bahadur Khadka ${ }^{1}$, Ram Asheshwar Mandal ${ }^{2 *}$, Ajay Bhakta Mathema ${ }^{3}$ \\ ${ }^{1}$ Department of Forests and Soil Conservation \\ ${ }^{2,3}$ School of Environmental Science and Management(SchEMS), Kathmandu, Nepal
}

\author{
*Corresponding Author: Ram Asheshwar Mandal, School of Environmental Science and \\ Management(SchEMS), Kathmandu, Nepal
}

\begin{abstract}
Forests offer life and love to the living beings therefore, they perform enormous functions like ecosystem services, biodiversity and carbon stock but such researches are limited in Nepal. Therefore, this study was objectively carried out to compare the growing stock, carbon stock and biodiversity in and around Banke National Park (BaNP). The map of the study was prepared it was divided into six blocks were delineated specifically. Altogether 90 sample plots, particularly, 15 plots in each block were laid in the field. Circular nested plots having 8.92, 5.64, 1 and $0.56 \mathrm{~m}$ radius were established in the field to measure tree, poles, sapling and seedlings respectively. The soil samples were collected from 0-10, 10-20, and 20-30 cm depth. The diameter (at $1.3 \mathrm{~m}$ ) and height of trees/poles/sapling were measured. The biomass was estimated using equation of Chave et al, and soil carbon was analyzed using Walkley and Black method. It was found that 104 trees/ha, 416poles/ha and 1991saplings/ha in BaNP. Volume of stems ( $110 \mathrm{~cm} \mathrm{DBH)} \mathrm{was} 5.54 \mathrm{~m}^{3} / \mathrm{ha}$ in B5 block while it was the lowest approximately $100.74 \mathrm{~m}^{3} /$ ha in B2 block. The t-test showed that there was no significance difference in average number of regeneration, sapling, pole, tree, basal area and volume between in and BaNP at 95\% confidence level (P>0.05). One-way ANOVA showed that there was no significance differences in number of sapling and tress per ha among B1, B3 and B5 inside BaNP. Above ground carbon stocks in BaNP and outside BaNP was 130.87 and 118.49 t/ha respectively. The ShannonWiener Index was the highest 3.27 in block B4. The IVIs of Shorea robusta were 110<IVI<40 and $80<I V I<70$ in BaNP outside BaNP respectively. This study will be useful for policy maker working conservation biology.
\end{abstract}

Keywords: Carbon, volume, biodiversity, importance value index

\section{INTRODUCTION}

There is imperative interrelationship between people and forests (Kirby \& Potvin, 2007; SchererLorenzen et al., 2005) because forests are very benign to them. In fact, the green forests are working as tireless apparatus of oxygen production which is the precious life gas for living beings (Grove, 1996). Forests produce timber and nontimber products. Besides, the forests function as ecosystem services, biodiversity kit and capture the $\mathrm{CO}_{2}$ produced during the respiration process of living beings(Gómez-Baggethun, De Groot, Lomas, \& Montes, 2010). This is why, life is impossible without green forests on the planet (Fisher, Turner, \& Morling, 2009; Pimentel et al., 1980). Globally, estimated annual deforestation was $-0.13 \%$ between 2000 and 2010 but it was positive change $0.28 \%$ in Asia (Schmitt et al., 2009). Moreover, the annual forest area loss in Terai, Nepal was $0.40 \%$ in between 1991 to 2010 (Oli \& Shrestha, 2009). However, present assessment showed the positive trend in forest in Nepal (DFRS, 2015). People and their poverty are equally responsible for mismanagement of forests (Desa, 2014).

Globally, middle class population expanded from 26\% to 58\% in between 1990 to 2010(Penafiel, Lachat, Espinel, Van Damme, \& Kolsteren, 2011). About 1.57 billion people or more than $30 \%$ of the population of the 104 countries counting Nepal live in multidimensional poverty (Malik, 2013). About 60 million people (especially indigenous peoples) are wholly dependent on forests for subsistence livelihood (Giri et al., 2011). So, only managing the forests is not the reliable solution to reverse the degraded and deforested lands without managing these people (Karsenty \& Ongolo, 2012; Mandal, Dutta, Jha, \& Karmacharya, 2015). 
Conservation of flora and fauna is international respect to the global treaty and Nepal recognized for this. Buffer zone was established first time in 1996 in Chitwan National Park and then extended to other conservation area too, in order to increase people's participation to conserve the flora and fauna. Banke National park is newly established national park in 2010 (DNPWC, 2019) but people nearby this are enthusiastic to manage the flora and fauna through buffer zone community forest. The assessment of this will be compelling ways (Mandal et al., 2015; Milder, Scherr, \& Bracer, 2010) because the important assumption of conservation is to increase the biodiversity, ecological value, carbon stock including growing stock in both core areas and buffer zone of national park. Such researches are very limited in Nepal thus it is essential to compare the growing stock including carbon stock, biodiversity and ecological value inside park and its surrounding i.e. buffer zone community forest.

\section{MATERials AND Methods}

Study area: Forests inside and around the Banke National Park (BaNP) was selected as study site. The site situated at $27^{\circ} 58^{\prime} 13^{\prime}$ to $28^{\circ} 21^{\prime} 26^{\prime \prime} \mathrm{N}$ latitude; and $81^{\circ} 39^{\prime} 29^{\prime \prime}$ to $82^{\circ} 12^{\prime} 19^{\prime \prime}$ E longitude. This park extends along the Churia foothills of the western part of Terai Arc Landscape of Nepal (Fig. 1). The national park was established in 2010 as an effort to conserve the tropical deciduous ecosystem to meet the national target of double the population of tiger Panthera tigris. The core zone of National park covers $550 \mathrm{~km}^{2}$ while the buffer zone is $343 \mathrm{~km}^{2}$. The elevation of study area ranges between 153 to $1,247 \mathrm{~m}$ above mean sea level. Mean maximum temperature is around $40{ }^{\circ} \mathrm{C}$ in summer but drops to very low during winter (DNPWC, 2019).

Sampling design: The map of the study site was prepared and it blocks were delineated. Total forest area was divided into six blocks, specifically, three blocks inside the BaNP and three blocks in buffere zone of BaNP with the help of staff and local people who were familiar with condition of the forest, such as species distribution, age, class, and crown density. These blocks were considered as strata to further distribute the plots randomly on it applying stratified random sampling. Altogether 90 sample plots, particularly, 15 sample plots in each block were laid in the field ( Ravindranath and Ostwald 2008). Circular nested plots having 8.92, 5.64, 1 and $0.56 \mathrm{~m}$ radius were established in the field to measure tree, poles, sapling and seedlings respectively. The soil samples were collected from 0-10, $10-20$, and $20-30 \mathrm{~cm}$ depth.

Data collection: The diameter (at $1.3 \mathrm{~m}$ ) and height of trees/poles/sapling (DBH> $5 \mathrm{~cm}$ ) were measured using diameter tape and clinometers respectively. All trees/poles inside the plot were marked to prevent double counting before measurement. Inventory was extended to record, sapling $(\mathrm{DBH}=1$ to $5 \mathrm{~cm})$ and seedling as well. Besides, the soil data was collected from 0-10, 10-20, and 20$30 \mathrm{~cm}$ depth (IPPC, 2006) using known volume soil corer.

Data analysis: All collected data were analyzed quantitatively. The biomass was calculated using equation developed by Chave et al., (2005) . AGTB $=0.0509 * \rho \mathrm{D}^{2} \mathrm{H}$, whereas AGTB $=$ above-ground tree biomass $(\mathrm{kg}) ; \rho=$ wood specific gravity $(\mathrm{kgm}-3) ; \mathrm{D}=$ tree diameter at breast height $(\mathrm{cm})$ and $\mathrm{H}=$ tree height $(\mathrm{m})$.

Besides, the fresh weight was taken of regeneration (sapling and seedling) and dried in the lab to find the dry weight. The unitary method was applied to determine the biomass of regeneration.

The carbon stock density of soil organic carbon was calculated using Walkley and Black (1958).

$\mathrm{SOC}=\rho \times \mathrm{d} \times \% \mathrm{C}$, whereas $\mathrm{SOC}=$ soil organic carbon stock per unit area [t ha $],$

$\rho($ Bulk Density $\mathrm{g} / \mathrm{cc})=$ (oven dry weight of soil)/ (volume of soil in the core), $\mathrm{d}=$ the total depth at which the sample was taken $[\mathrm{cm}]$, and $\% \mathrm{C}=$ carbon concentration [\%].

\subsection{Calculation of Biodiversity Index Calculation}

The species diversity of the forest tree community was calculated to using different indices.

Shannon-Wiener index (H) $=-\sum \mathrm{Pi} \log \mathrm{Pi}$, where $\mathbf{P i}=$ ni / N

Whereas, $\mathrm{N}=$ Total no of species, $\mathrm{ni}=$ no. of individuals of species and $\mathrm{Pi}=\mathrm{ni} / \mathrm{N}$

Index of Dominance $(\boldsymbol{C})=-\sum(\mathrm{ni} / \mathrm{N})^{2}$ (Simpson 1949), Whereas, $\mathrm{ni}=$ number of individuals of each species \& $\mathrm{N}=$ total number of individuals 


\section{EVENNESS INDEX $(e)=\mathrm{H}^{\prime} / \log \mathrm{S}($ Odum1967)}

Whereas $H^{\prime}=$ Shannon -Wiener Diversity Index and $\mathrm{S}=$ numbers of species

Density shows the number of individual trees per unit area and it indicates the numerical strength of a species in a community (Zobel et al. 1987).

Density $=\frac{\text { Number of individual of the species }}{\text { Total no.of plots studied } x \text { area of each plot }} \times 100$

Relative density $=\frac{\text { Number of individual of the species }}{\text { Number of individual of all the species }} \mathbf{x 1 0 0}$

Frequency indicates the dispersion of species in a community. It is the percentage of sampling units in which a particular species occurs.

Relative frequency $\quad=\frac{\text { Number of occurrence of the species }}{\text { Number of occurrence of all the species }} \mathbf{x 1 0 0}$

Basal area refers to the ground actually penetrated by the stems (Hanson \& Churchill 1961).

Basal area $(\mathrm{m})=(3.1416) \times(\mathrm{dbh}) 4$

Relative dominance $=\frac{\text { Total basal area of the species }}{\text { Total basal area of all the species }} \mathbf{x 1 0 0}$

$\mathrm{IVI}=\sum$ of Relative density + Relative frequency + Relative dominance (Curtis and McIntosh, 1950). proposed an index known as Importance Value Index (IVI) to express the dominance and ecological

Besides, simple and inferential statistics were applied to present and compare the quantitative data statistically.

\section{RESUlts}

\subsection{Comparison of Growing Stock Between the Studies Block in and Outside BaNP}

It was found that 104 trees/ha, 416poles/ha and 1991saplings/ha in BaNP. On the other hand 94 trees/ha, 375poles/ha and 1831 saplings/ha outside the BaNP.

Table1. Growing stock in studied block in BaNP and outside the BaNP

\begin{tabular}{|c|c|c|c|c|c|c|}
\hline NP/ONP & $\begin{array}{c}\text { Regenerations } \\
\text { No/ha }\end{array}$ & $\begin{array}{c}\text { Saplings } \\
\text { No/ha }\end{array}$ & $\begin{array}{c}\text { Poles } \\
\text { No/ha }\end{array}$ & $\begin{array}{c}\text { Trees } \\
\text { No/ha }\end{array}$ & $\begin{array}{c}\text { Basal } \\
\text { area(m } \mathbf{m}^{2} / \mathbf{h a}\end{array}$ & $\begin{array}{c}\text { Volume } \\
(\mathbf{m 3}) / \mathbf{h a}\end{array}$ \\
\hline NP & 33906 & 1991 & 416 & 104 & 24.61 & 225.51 \\
\hline ONP & 33005 & 1831 & 375 & 94 & 23.27 & 198.28 \\
\hline
\end{tabular}

NP=Banke National Park

ONP=Outside Banke National Park

Moreover, the result showed that basal area of stems $(\geq 10 \mathrm{~cm}$ DBH) was also highest inside Banke National Park then outside Banke National Park. i.e. $24.61 \mathrm{~m} 2 /$ hain the studied blocks inside the BaNP and at the studied blocks outside the BaNP basal area of stems $(\geq 10 \mathrm{~cm}$ DBH) was 23.27 $\mathrm{m}^{2} /$ ha.Stem volume was also found inside BaNP i.e. $225.51 \mathrm{~m}^{3} / \mathrm{ha}$ inside the BaNP and $198.28 \mathrm{~m}^{3} / \mathrm{ha}$ outside the BaNP.

The growing stocks also varied according to blocks inside and outside national park. More specific, it was the highest around $315.54 \mathrm{~m}^{3} / \mathrm{ha}$ in B5 block while it was the lowest approximately $100.74 \mathrm{~m}^{3} / \mathrm{ha}$ in B2 block (Table 2).

Table2. Block wise growing stock inside and outside national park

\begin{tabular}{|c|c|c|c|c|c|c|c|c|}
\hline \multirow{2}{*}{ Description } & \multicolumn{4}{|c|}{ In BaNP } & \multicolumn{4}{c|}{ Outside BaNP } \\
\cline { 2 - 9 } & B1 & B3 & B5 & Average & B2 & B4 & B6 & Average \\
\hline $\begin{array}{c}\text { Sapling (DBH } \\
1 \text { to } 10 \mathrm{~cm}) / \mathrm{ha}\end{array}$ & 583 & 493 & 548 & 541 & 517 & 615 & 395 & 509 \\
\hline Pole & 152 & 157 & 72 & 127 & 110 & 141 & 63 & 104 \\
\hline Tree & 56 & 93 & 88 & 79 & 50 & 64 & 85 & 67 \\
\hline $\begin{array}{c}\text { Basal area } \\
\left(\mathrm{m}^{2}\right) / \mathrm{ha}\end{array}$ & 13.29 & 22.14 & 24.56 & 20.00 & 12.88 & 20.38 & 23.28 & 18.85 \\
\hline $\begin{array}{c}\text { Volume } \\
\left(\mathrm{m}^{3}\right) / \mathrm{ha}\end{array}$ & 153.90 & 198.12 & 315.54 & 222.52 & 100.74 & 214.33 & 254.45 & 189.84 \\
\hline
\end{tabular}


Moreover, the result showed that basal area of stems $(\geq 10 \mathrm{~cm} \mathrm{DBH})$ was also highest inside Banke National Park then outside Banke National Park. i.e. $24.61 \mathrm{~m} 2 /$ hain the studied blocks inside the $\mathrm{BaNP}$ and at the studied blocks outside the BaNP basal area of stems $(\geq 10 \mathrm{~cm}$ DBH) was 23.27 $\mathrm{m} 2 / \mathrm{ha}$.Stem volume was also found inside BaNP i.e. $225.51 \mathrm{~m}^{3} / \mathrm{ha}$ inside the BaNP and $198.28 \mathrm{~m} 3 / \mathrm{ha}$ outside the BaNP.

The growing stocks also varied according to blocks inside and outside national park. More specific, it was the highest around $315.54 \mathrm{~m}^{3} / \mathrm{ha}$ in B5 block while it was the lowest approximately $100.74 \mathrm{~m}^{3} / \mathrm{ha}$ in B2 block (Table 2).

The t-test showed that there was no significance difference in average number of regeneration, sapling, pole, tree, basal area and volume between studies blocks B1 and B2, B3 and B4 and B5 and B6 at $95 \%$ confidence level since the $\mathrm{p}$-value which is greater than 0.05 .

In addition, One-way ANOVA and Post Hoc multiple showed that there was no significance differences in blocks B1, B3 and B5 in number of sapling $(p=0.474)$ and trees $(p=0.085)$ except number of pole $(\mathrm{p}=0.012)$ inside BaNP. Similar result was found in comparison of number of stands among B2, B4 and blocks outside BaNP.

Above and below ground Vegetation (Tree and sapling) carbon: The mean above-ground tree biomass inside BaNP was found to be $277.85 \pm 2.60$ t/ha which was higher than studies blocks of outside BaNP (251.57 \pm 2.41$)$ (Table 1). Similarly, the above-ground sapling biomass was also found to be higher in BaNP $(0.58 \pm 0.01 \mathrm{t} / \mathrm{ha})$ than outside BaNP $(0.54 \pm 0.01 \mathrm{t} / \mathrm{ha})$. Carbon stocks in aboveground vegetation in BaNP and outside BaNP was found to be 130.87 and 118.49 t/ha respectively (Table 3).

Table3. Above-ground vegetation biomass and carbon stock (Mean $\pm S E$, $t / h a)$

\begin{tabular}{|c|c|c|c|c|c|c|}
\hline Area & AGTB & Carbon & AGSB & Carbon & Total biomass & Total Carbon \\
\hline In BaNP & $\mathbf{2 7 7 . 8 5} \pm 2.60$ & $\mathbf{1 3 0 . 5 9} \pm 2.51$ & $\mathbf{0 . 5 8} \pm 0.01$ & $\mathbf{0 . 2 8} \pm .01$ & $\mathbf{2 7 8 . 4 3}$ & 130.87 \\
\hline Outside BaNP & $\mathbf{2 5 1 . 5 7} \pm 2.41$ & $\mathbf{1 1 8 . 2 4} \pm 2.38$ & $\mathbf{0 . 5 4} \pm 0.01$ & $\mathbf{0 . 2 5} \pm 0.01$ & $\mathbf{2 5 2 . 1 1}$ & $\mathbf{1 1 8 . 4 9}$ \\
\hline
\end{tabular}

Below ground biomass in and outside BaNP was found to be $41.85 \pm 1.63$ and $37.82 \pm 1.31 \mathrm{t} / \mathrm{ha}$ respectively while the carbon stocks in belowground vegetation in and outside BaNP was found to be $19.63 \pm 1.89$ and $17.78 \pm 1.58$ t/ha respectively.

Bulk density and Soil carbon change in and outside BaNP: There was a variation in the bulk density (BD) with respect to depth in forest soils in studies blocks of both in and outside BaNP. Indeed there was a gradual increment in the BD with the increase in soil depth in both forests. The range of bulk density in two different forests based on the entire profile $(0-30 \mathrm{~cm})$ depths has been presented in Table (6). Accordingly the lowest BD was found at the top soil $(0-10 \mathrm{~cm})$ in the both case in and outside BaNP whereas highest BD was recorded at the depth of $20-30 \mathrm{~cm}$ in studies blocks outside BaNP (Table 6). The SOC was higher at the upper layers that gradually decreased in the soil depth. Table 7 presents the depth-wise distribution of SOC stock in and outside BaNP. Accordingly the maximum SOC was found at the top soil $(0-10 \mathrm{~cm})$ and sub soil $(10-20)$ in BaNP whereas the minimum SOC was reported at the depth of 20-30 cm in both case of in and outside BaNP (Table 7). The total SOC was also higher in BaNP (68.42 t/ha) than in the studies blocks of outside BaNP(59.59) (Table 4).

Table4. Bulk density soil organic carbon (t/ha)inin and outside BaNP

\begin{tabular}{|l|l|l|l|l|}
\hline \multirow{2}{*}{ Soil Depth (cm) } & \multicolumn{3}{|l|}{ In BaNP } & \multicolumn{2}{l|}{ Outside BaNP } \\
\cline { 2 - 5 } & BD Mean $(\mathbf{g} / \mathbf{m} 3) \pm$ SD & SC \pm SD & Mean $(\mathbf{g} / \mathbf{m} 3) \pm$ SD & SC \pm SD \\
\hline $0-10$ & $1.11 \pm 0.08$ & $27.36 \pm 2.33$ & $0.98 \pm .1$ & $23.6 \pm 2.63$ \\
\hline $20-$ Oct & $1.18 \pm .07$ & $22.94 \pm 2.78$ & $1.12 \pm .06$ & $19.38 \pm 2.34$ \\
\hline $20-30$ & $1.24 \pm .07$ & $18.12 \pm 1.13$ & $1.19 \pm .04$ & $16.61 \pm 1.44$ \\
\hline
\end{tabular}

Total carbon sequestration was higher in BaNP (218.92 t/ha) than outside BaNP (195.86 t/ha) (Table 8). Total carbon sequestration in BaNP was $130.87 \mathrm{t} / \mathrm{ha}$ by above ground, $68.42 \mathrm{t} / \mathrm{ha}$ by the soil and 19.63 t/ha by the root (Table 8). Similarly, Carbon sequestration outside BaNP was contributed to $118.49 \mathrm{t} / \mathrm{ha}$ by above ground, $59.59 \mathrm{t} / \mathrm{ha}$ by the soil; and $17.78 \mathrm{t} / \mathrm{ha}$ by the root. 


\section{Biodiversity index inside the BaNP and outside BaNP}

The species diversity (Shannon-Wiener Index) of the BaNP was (H') 2.50and outside the BaNp was (H') 2.85 (Table 5). In the comparative study of sp. diversity index within the studied Block, the highest value of sp. diversity was found in block B4 i.e. (H) 3.27, which was followed by block B2 $(\mathrm{H}=2.74)$ both block lies outside the BaNP (Table 2). The lowest value of diversity index was found in block B1 $(\mathrm{H}=2.16)$ which lies in BaNP.

Table5. Biodiversity index of Vegetation in BaNP and outside the BaNP

\begin{tabular}{|l|l|l|l|l|l|l|l|}
\hline Parameters & $\begin{array}{c}\text { Number of } \\
\text { species }\end{array}$ & $\begin{array}{c}\text { Species } \\
\text { diversity } \\
\left(\mathrm{H}^{\prime}\right)\end{array}$ & $\begin{array}{c}\text { Index of } \\
\text { Dominance } \\
(\mathrm{c})\end{array}$ & $\begin{array}{c}\text { Evennes } \\
\text { s Index } \\
(\mathrm{e})\end{array}$ & $\begin{array}{c}\text { Mean } \\
\text { dbh } \\
(\mathrm{cm})\end{array}$ & $\begin{array}{c}\text { Mean } \\
\text { height } \\
(\mathrm{m})\end{array}$ & $\begin{array}{c}\text { Tree } \\
\text { density(No/ha) }\end{array}$ \\
\hline Inside BaNP & 21.33 & 2.50 & 0.46 & 1.89 & 26.43 & 15.61 & 624.44 \\
\hline outside BaNP & 18.67 & 2.85 & 0.27 & 2.24 & 26.33 & 14.21 & 568.89 \\
\hline
\end{tabular}

The index of dominance (c) was 0.46 in the BaNP (i.e. B1=0.19, B3=1.1, B5=0.1) and 0.27 outside the BaNP (B2=0.42, B4=0.32, B6=0.08). The highest dominance (c) was found to be 1.1 in block B3 (inside the BaNP) whereas the lowest index of dominance (c) was 0.08 in block B6 (outside the BaNP).

Evenness index (e) of the BaNP was found to be 1.89 and outside the BaNP was 2.24(Table 1). Block wise it ranged from 1.72 to 2.04 in BaNP and Block wise range outside the BaNP was from 1.98 to 2.56. Lowest species evenness was found in Block B1 (1.2) which lies in BaNP and highest in block B4 (2.56) which lies outside the BaNP.

The Biodiversity index of the vegetation in studied 6 Block

\begin{tabular}{|c|c|c|c|c|c|c|c|}
\hline $\begin{array}{c}\text { BLOC } \\
\text { K }\end{array}$ & $\begin{array}{c}\text { Number } \\
\text { of species }\end{array}$ & $\begin{array}{c}\text { Shannon- } \\
\text { Wiener } \\
\text { Index (H') }\end{array}$ & $\begin{array}{c}\text { Index of } \\
\text { Dominance (c) }\end{array}$ & $\begin{array}{c}\text { Evenness } \\
\text { Index (e) }\end{array}$ & $\begin{array}{c}\text { Mean } \\
\text { dbh (cm) }\end{array}$ & $\begin{array}{c}\text { Mean } \\
\text { height (m) }\end{array}$ & $\begin{array}{c}\text { Tree } \\
\text { density(No/ha) }\end{array}$ \\
\hline B1 & 18 & 2.16 & 0.19 & 1.72 & 21 & 15.04 & 627 \\
\hline B3 & 26 & 2.69 & 1.1 & 1.90 & 22.24 & 11.48 & 833 \\
\hline B5 & 20 & 2.66 & 0.1 & 2.04 & 36.06 & 20.30 & 413 \\
\hline B2 & 18 & 2.74 & 0.42 & 2.18 & 18.70 & 13.08 & 660 \\
\hline B4 & 19 & 3.27 & 0.32 & 2.56 & 23.77 & 12.07 & 660 \\
\hline B6 & 19 & 2.53 & 0.08 & 1.98 & 36.52 & 17.47 & 387 \\
\hline
\end{tabular}

Block inside $\mathrm{BaNP}=\mathrm{B} 1, \mathrm{~B} 3, \mathrm{~B} 5 \quad$ Block outside $\mathrm{BaNP}=\mathrm{B} 2$, B4, B6

\section{Ecological value inside the BaNP and outside BaNP}

Curtis and McIntosh (1950) proposed an index known as Importance Value Index (IVI) to express the dominance and ecological success of any species with a single value. This index was calculated to determine the overall importance of each species in the community structure. The Importance Value Index (IVI) provides the picture of the relative contribution of a species to the entire community.

The results showed that IVIs of plant species were differed according to studies blocks. Specifically, the highest IVI was recorded for Shorea robusta in all studies blocks. They were $110<\mathrm{IVI}<40$ and $80<\mathrm{IVI}<70$ in studied in BaNP outside BaNP respectively. Additionaly, there were some more high records of IVIs of Terminalia tomentosa in some studied block in and outside BaNP ranging from $70<\mathrm{IVI}<20$ and $30<\mathrm{IVI}<18$ respectively (Table 6 ).

Table6. IVI of major species inside the BaNP and outside BaNP

\begin{tabular}{|c|c|c|c|c|c|c|}
\hline \multirow{2}{*}{ Species } & \multicolumn{2}{|c|}{ IVI of Inside Banke NP } & \multicolumn{3}{c|}{ IVI of outside Banke NP } \\
\cline { 2 - 7 } & Average & Max. & Min. & Average & Max. & Min. \\
\hline Shorea robusta & 71.20 & 108.81 & 40.49 & 80.88 & 86.41 & 69.90 \\
\hline Terminalia tomentosa & 41.59 & 71.27 & 21.18 & 22.98 & 31.65 & 18.26 \\
\hline Anogeissus latifolia & 24.04 & 40.83 & 12.37 & 41.08 & 50.00 & 35.79 \\
\hline Bombax ceiba & 17.67 & 17.67 & 17.67 & 4.48 & 4.48 & 4.48 \\
\hline Lagestomia parviflora & 16.80 & 24.10 & 12.10 & 29.05 & 36.76 & 22.61 \\
\hline Dillenia pentagyna & 13.74 & 17.44 & 8.75 & 9.59 & 13.42 & 4.55 \\
\hline Buchanania latifolia & 11.51 & 17.02 & 7.63 & 13.17 & 17.24 & 7.96 \\
\hline Gardenia augusta & 10.62 & 18.62 & 4.83 & 12.99 & 17.18 & 8.94 \\
\hline Semecarpus anacardium & 10.02 & 11.01 & 8.05 & 8.11 & 10.78 & 5.43 \\
\hline
\end{tabular}

International Journal of Advanced Research in Botany (IJARB) 


\begin{tabular}{|c|c|c|c|c|c|c|}
\hline Diospyros malabarica & 9.80 & 11.76 & 7.83 & 9.33 & 14.44 & 5.47 \\
\hline Terminalia bellirica & 9.69 & 14.13 & 6.96 & 11.04 & 21.34 & 5.62 \\
\hline Phyllanthus nepalensis & 9.32 & 10.46 & 8.60 & 10.99 & 15.22 & 6.29 \\
\hline Garuga pinnata & 9.21 & 9.21 & 9.21 & 8.76 & 13.44 & 4.08 \\
\hline Stereospermum tetragonum & 9.01 & 9.01 & 9.01 & 6.19 & 6.19 & 6.19 \\
\hline Schleichera oleosa & 8.63 & 10.75 & 6.50 & 7.58 & 7.58 & 7.58 \\
\hline Mallotus philippensis & 6.87 & 6.87 & 6.87 & 5.00 & 5.00 & 5.00 \\
\hline Syzygium cumini & 6.26 & 6.26 & 6.26 & 11.10 & 13.40 & 8.80 \\
\hline Mahua longifolia & 6.14 & 6.34 & 5.94 & 8.43 & 11.28 & 5.29 \\
\hline Careya arborea & 5.10 & 8.58 & 2.84 & 8.12 & 11.58 & 4.66 \\
\hline Bixa orellana & 4.05 & 4.05 & 4.05 & 4.84 & 5.29 & 4.39 \\
\hline
\end{tabular}

\section{DISCUSSION}

The number of stems (DBH $<\mathbf{1 0} \mathbf{~ c m}) 37838$ per hectare inside the BaNP and 36815 outside the BaNP. The average number of seedlings $(<1.3 \mathrm{~m}$ height) was 37,297 per hectare in BaNP and 36,306 outside the BaNP. Saplings ( $\geq 1.3 \mathrm{~m}$ height and $<5 \mathrm{~cm} \mathrm{DBH})$ and bigger saplings $(5-10 \mathrm{~cm} \mathrm{DBH})$ were 498 and 44 per hectare inside the BaNP and 460 and 49 per hactare outside the BaNP. An analysis of DBH classes of stems $(\mathbf{D B H}<\mathbf{1 0} \mathbf{~ c m})$ revealed that the proportion of small stems was higher than that of large ones both in the studies blocks in and outside BaNP. This shows the high regeneration capacity and could exploit environmental conditions efficiently for seed germination and seedling establishment. From the study it was found that the regeneration of the park was good. (Rautiainen, 1996) and (Webb \& Sah, 2003) also reported good regeneration of Sal in the Terai of Nepal. However, regeneration potential of other trees was very low since the combined densities of seedlings of all other trees were very low as compared to S. robusta, A. latifolius and T. alata. (Timilsina, Ross, $\&$ Heinen, 2007)also reported low mean seedling density $(0.861 \mathrm{pl} / \mathrm{m} \mathrm{2})$ of all other tree species in comparison to Sal $(7.0462 \mathrm{pl} / \mathrm{m} \mathrm{2})$ in Sal forest of western Terai. This study is very similar to the recent study of Napit 2015 in BaNP that the seedling density of the park ranged from 634-59235.7 /ha.

The estimate Stems (DBH $\geq 10 \mathrm{~cm}$ ) density 206 stems/ha in BaNP and 171 stems/ha outside BaNP which was very lower than total density of the tree species in the same study area BaNP ranged from 82.8 to 633.8 plants/ha (Napit, 2015a), Churia forest of Rupandehi district from 1092-1153 plants/ha (Marasini, 2003)and in tropical forest of Palpa district 654 plants/ha Bashyal (2005), the value reported for sal forest by (A. Giri et al., 1999)in Bardia National Park (258 - 384 plants/ha). Lower total tree density in the present study area than the reported values for tropical forest might be due to over exploitation of the studied forest in the past.

The study estimated basal area of stems $20.00 \mathrm{~m} 2 / \mathrm{ha}$ in BaNP and $18.85 \mathrm{~m} 2 / \mathrm{ha}$ outside BaNP. The basal area is an important criterion for evaluating the timber production in forest ecosystem (Agrawal 1992), an indication of the natural fertility of the site (Bruening 1968) and maturity/age group of the forests. The estimated average BA of this park was quite similar to several other reports for S. robusta forests, for example, The average BA of the BaNP $21.13 \mathrm{~m} 2 / \mathrm{ha}$ (Napit, 2015b), BA of $29-36 \mathrm{~m}^{2} / \mathrm{ha}$ for sal forests of Bardia National Park (Aryal 1997), $37.28 \mathrm{~m}^{2} / \mathrm{ha}$ for Churia forest in eastern Nepal(Bhuju \& Yonzon, 2004). But in contrast, it was lower than the value of BA $63.86 \mathrm{~m} 2 / \mathrm{ha}$ reported by Bashyal (2005) for tropical forest of Palpa district and $76 \mathrm{~m} 2 /$ ha as reported by Sejuwal(1994)in the S. robusta forest of Chitwan National Park. The basal area and volume are an important criterion for evaluating the timber production in forest ecosystem (Agrawal 1992), an indication of the natural fertility of the site (Bruening 1968) and maturity/age group of the forests.

This study shows Stem volume had highest (222.52 m3/ha) in BaNP then outside the BaNP (189.84 $\mathrm{m} 3 / \mathrm{ha}$ ). The estimated value of this study is slightly lager the the average stem volume (161.66 $\mathrm{m} 3 / \mathrm{ha}$ ) of Terai(DFRS, 2015).

Carbon stocks in above-ground vegetation in BaNP and outside BaNP was found to be 130.87 and $118.49 \mathrm{t} / \mathrm{ha}$ respectively (Table 1). Carbon stocks in belowground vegetation in and outside BaNP was found to be $19.63 \pm 1.89$ and $17.78 \pm 1.58$ t/ha respectively.

Kafle reported that $58.82 \mathrm{t} / \mathrm{ha}$ in a Shorea robusta forest of Makawanpur district of Nepal(2014), our findings are closer to this value. Soil organic carbon stocks in forest soils fluctuate from 50 to more than 200 Mgha-1, depending on climate and soil conditions, the age and type of the tree stand, and 
management practices(Ostrowska, Porębska, \& Kanafa, 2010). Higher amount of SOC found in the study could be also due to the higher density of saplings and regenerations and its organic residues.

Nepal reported that the carbon stock density in a Shorea robusta forest in a community forest of Palpa district to be $186.95 \mathrm{t} / \mathrm{ha}(2006)$. Shrestha found $235.95 \mathrm{t} / \mathrm{ha}$ carbon stock density in a Shorea robusta forest of the hilly region(2008). The values are closer and the variation in values could be due to other factors such as stand density. The values of carbon stock density in this study was found higher than the average carbon stock in Nepalese forest (161.1 t ha-1) estimated by the Global Forest Resource Assessment Report of FAO (2006). FAO used the projected Forest Inventory data of 1994 in its report that might be the reason for this(2006). Baral et al. also reported that total carbon stock of Shorea robusta forest was higher than that of pine forest(2009). The rate of carbon sequestration by different forest types depended on the growing nature of the forest stands. Moreover temperature and moisture, which vary with altitude, are major climatic factors responsible for determining the decomposition rate of organic carbon (Amundson, 2001). Litter fall and root turnover are critical components of ecosystem nutrient cycling and carbon sequestration (Gill \& Jackson, 2000). Shrestha and Singh also reported higher carbon stocks of vegetation and soil in Shorea robusta than in the pine forest(2008). The total carbon stock in Nepal's forest has been estimated as 1,054.97 million $\mathrm{t}$ (176.95 t/ha). Out of this, tree component (live, dead standing, dead wood and below-ground biomass), forest soils, and litter and debris constitute $61.53 \%, 37.80 \%$, and $0.67 \%$, respectively (DFRS, 2016). Banke National park have contributed in such way to global climate change mitigation.

There was a variation and a gradual increment in the bulk density (BD) with respect to depth in forest soils in studies blocks of both in and outside BaNP. The lowest BD was found at the top soil $(0-10$ $\mathrm{cm}$ ) and highest BD was recorded at the depth of $20-30 \mathrm{~cm}$ in the both studies blocks in and outside BaNP.

The total SOC was also higher in BaNP (68.42 t/ha) than in the studies blocks of outside BaNP(59.59). The SOC was higher at the upper layers that gradually decreased in the soil depth. The maximum SOC was found at the top soil $(0-10 \mathrm{~cm})$ and sub soil $(10-20)$ whereas the minimum SOC was reported at the depth of $20-30 \mathrm{~cm}$ in both case of in and outside BaNP. SOC diminishes with the depth of the profile (Trujillo et al., 1997). The higher organic carbon percentage in the top layer may be due to rapid decomposition of forest litter in a favorable environment. Pandey and Bhusal (2016) reported that the SOC decreased with the increase in soil depth in Terai regions of Nepal.

Shannon-Weiner biodiversity index was the highest 2.33 in Banke- Maraha CFM but it was the lowest 2.21 in Gadhanta- Bardibash CFM and the record of this was 2.28 in Tuteshwarnath CFM. Similarly, the records this were 2.40, 2.37 and 1.93 in Chure- Parwati CF, Chyandanda CF and Baudh CF respectively (Mandal et al., 2013). The IVI was the highest recorded in Shorea robusta and followed by Terminalia tomentosa (Chandran et al., 2010, Chaubey, 2012). Mandal et al., 2013) these values were not exactly matching with our studies but the IVI values were similar. The reason behind this may be due to geographical and climatic factors our study site was at west while this was in centre region of Nepal. The Simpson diversity index was the highest $(0.742 \pm 0.018)$ value was found in 7-yr old forest of Kapilwastu district Nepal (Oli et al., 2019). The values are about similar because geography and climate of Banke and Kapilwastu district are quite similar.

\section{CONCLUSION AND RECOMMENDATION}

The total carbon stock as revealed form this study was higher in (218.92 t/ha) than outside BaNP (195.86 t/ha). Likewise soil organic carbon (SOC) decreased with the increase in soil-depth in both the forests inside and outside Banke National Park. Total carbon stock of BaNP was higher than that of outside BaNP. It can be thus concluded that forest under the protected areas of Nepal had higher amount of total carbon stock per hectare compared to the forest outside the protected area. Both forest inside and outside the BaNP are important for sinking carbon, hence contributing to climate change mitigation.

\section{ACKNOWLEDGEMENT}

We acknowledge School of Environmental Science and Management for technical support in lab facility and equipment.

\section{REFERENCES}

[1] Amundson, R. (2001). The carbon budget in soils. Annual Review of Earth and Planetary Sciences, 29(1), 535-562.

[2] Baral, S. K., Malla, R., \& Ranabhat, S. (2009). Above-ground carbon stock assessment in different forest types of Nepal. Banko Janakari, 19(2), 10-14. 
[3] Bhuju, D. R., \& Yonzon, P. B. (2004). Species maintenance in a dynamic landscape: ecology of the Churia (Siwaliks) in Nepal Himalayas. Annual Report of Pro Natura Fund, 13, 155-175.

[4] Chandran, M.D.S., Rao, G.R., Gururaja, K.V., Ramchandra T.V. (2010). Ecology of the Swampy Relic Forestsmof Kathalekhan from Central Western Ghat India, Bioremediation, Biodiversity and Bioavailability. Global science books. Energy and Wetland Research Group, Centre for Ecological Sciences. Indian Institute of Sciences Bangalore 560012 India, (1).

[5] Chaubey, O.P. (2012). Eco-silviculture Options for Sustainable Forest Management in Joint Forest management- A case study of Mixed Forests of Madhya Pradesh of India, International Journal of Bioscience and Biotechnology, 4 (1), (2012), 1-16.

[6] Chave, J., Andalo, C., Brown, S., Cairns, M. A., Chambers, J. Q., Eamus, D., ... Kira, T. (2005). Tree allometry and improved estimation of carbon stocks and balance in tropical forests. Oecologia, 145(1), 8799.

[7] Desa, U. N. (2014). World urbanization prospects, the 2011 revision. Population Division, Department of Economic and Social Affairs, United Nations Secretariat.

[8] DFRS. (2015). DFRS, 2015. State of Nepal's Forests. Forest Resource Assessment (FRA) Nepal, Department of Forest Research and Survey (DFRS). Kathmandu, Nepal.

[9] DNPWC, 2019. Banke National Park, Department of National Park and Wildlife Conservation, Kathmandu Nepal https://www.dnpwc.gov.np/protected_areas/details/bankenationalparkFAO. (2006). FAO.(2006). Global Forest Resource Assessment Report.Food and Agriculture Organization of the United Nations (FAO), Rome, Italy.

[10] Fisher, B., Turner, R. K., \& Morling, P. (2009). Defining and classifying ecosystem services for decision making. Ecological Economics, 68(3), 643-653.

[11] Gill, R. A., \& Jackson, R. B. (2000). Global patterns of root turnover for terrestrial ecosystems. New Phytologist, 147(1), 13-31.

[12] Giri, A., Aryal, B., Bhattarai, B., Ghimire, S. K., Shrestha, K. K., \& Jha, P. K. (1999). Vegetation composition, biomass production and regeneration in Shorea robusta forests in the Royal Bardia National Park, Nepal. Nepal Journal of Science and Technology, 1(1).

[13] Giri, C., Ochieng, E., Tieszen, L. L., Zhu, Z., Singh, A., Loveland, T., ... Duke, N. (2011). Status and distribution of mangrove forests of the world using earth observation satellite data. Global Ecology and Biogeography, 20(1), 154-159.

[14] Grove, R. H. (1996). Green imperialism: colonial expansion, tropical island Edens and the origins of environmentalism, 1600-1860. Cambridge University Press.

[15] Innes, J. L. (n.d.). Forests in Environmental Protection, 7.

[16] IPPC. (2006). IPCC (2006) Good practice guidelines for national greenhouse gas inventories. Switzerland: Intergovernmental Panel on Climate Change.

[17] Kafle, G. (2014). Kafle, G. (2014). Vertical patterns of soil organic carbon and nitrogen in Pinus roxburghii and Pinus wallichiana forests of Daman hills, Nepal. AFU Research Reports (Volume I).Directorate of Research and Extension, Agriculture and Forestry University, Nepal.

[18] Karsenty, A., \& Ongolo, S. (2012). Can "fragile states" decide to reduce their deforestation? The inappropriate use of the theory of incentives with respect to the REDD mechanism. Forest Policy and Economics, 18, 38-45.

[19] Kirby, K. R., \& Potvin, C. (2007). Variation in carbon storage among tree species: implications for the management of a small-scale carbon sink project. Forest Ecology and Management, 246(2-3), 208-221.

[20] Malik, K. (2013). Human development report 2013. The rise of the South: Human progress in a diverse world.

[21] Mandal Ram Asheshwar, Yadav Bechu Kumar Vinwar, Yadav Kamlesh Kumar, Dutta Ishwar Chandra, Haque Shamsul Mohamad, 2013. Biodiversity comparison of natural Shorea robusta mixed forest with Eucalyptus camaldulensis plantation in Nepal Scholars Academic Journal of Biosciences (SAJB) 1(5):144-149.

[22] Mandal, R. A., Dutta, I. C., Jha, P. K., \& Karmacharya, S. B. (2015). EFFECTS OF FOREST CARBON ON ECOLOGICAL VALUE OF SPECIES IN COLLABORATIVE FORESTS, TARAI, NEPAL. International Journal of Conservation Science, 6(3).

[23] Marasini, S. (2003). Vegetation analysis of Churiya forest in Rupandehi, Nepal (PhD Thesis). M. Sc. thesis. Central Department of Botany, Tribhuvan University, Kathmandu ....

[24] Milder, J. C., Scherr, S. J., \& Bracer, C. (2010). Trends and future potential of payment for ecosystem services to alleviate rural poverty in developing countries. Ecology and Society, 15(2).

[25] Napit, R. (2015a). Species Diversity, Forest Community Structure and... - Google Scholar. Retrieved January 27, 2019, from https://scholar.google.com/scholar?hl=en\&as_sdt=0\%2C5\&q=Species+ Diversity $\% 2 \mathrm{C}+$ Forest+Community+Structure+and+Regeneration+in+Banke+National+Park\&btnG= 
[26] Napit, R. (2015b). Species Diversity, Forest Community Structure and Regeneration in Banke National Park. Nepal Journal of Science and Technology, 16(1), 17-30.

[27] Nepal, S. (2006). A Comparative study on Carbon Sequestration from two forest types in Community Forestry System (A case study from coniferous and broad leaved forests in Palpa District. Sc Thesis Submitted to Tribhuwan University, Institute of Forestry.

[28] Oli, B. N., \& Shrestha, K. (2009). Carbon status in forests of Nepal: An overview. Journal of Forest and Livelihood, 8(1), 62-66.

[29] Oli Yom Bahadur, Mandal Ram Aseshwar, 2019. Tree Species Diversity, Composition, Stocks and Soil Nutrients Dynamics Due to Management Practice in Collaborative Forests. Journal of Aquatic Science and Marine Biology Volume 2, Issue 1, 2019, PP 19-25

[30] Ostrowska, A., Porębska, G., \& Kanafa, M. (2010). Carbon accumulation and distribution in profiles of forest soils. Polish Journal of Environmental Studies, 19(6), 1307-1315.

[31] Penafiel, D., Lachat, C., Espinel, R., Van Damme, P., \& Kolsteren, P. (2011). A systematic review on the contributions of edible plant and animal biodiversity to human diets. EcoHealth, 8(3), 381-399.

[32] Pimentel, D., Garnick, E., Berkowitz, A., Jacobson, S., Napolitano, S., Black, P., ... Liftman, S. (1980). Environmental quality and natural biota. BioScience, 30(11), 750-755.

[33] Rautiainen, O. (1996). Regeneration status of sal (Shorea robusta Gaertn. f) in Bara district, Nepal. Banko Janakari, 6(1), 26-32.

[34] Ravindranath, N. H., \& Ostwald, M. (2008). Carbon inventory methods for national greenhouse gas inventory. Carbon Inventory Methods Handbook for Greenhouse Gas Inventory, Carbon Mitigation and Roundwood Production Projects, 217-235.

[35] Scherer-Lorenzen, M., Potvin, C., Koricheva, J., Schmid, B., Hector, A., Bornik, Z., ... Schulze, E.-D. (2005). The design of experimental tree plantations for functional biodiversity research. In Forest diversity and function (pp. 347-376). Springer.

[36] Schmitt, C. B., Burgess, N. D., Coad, L., Belokurov, A., Besançon, C., Boisrobert, L., ... Humphries, K. (2009). Global analysis of the protection status of the world's forests. Biological Conservation, 142(10), 2122-2130.

[37] Sejuwal, M. (1994). Above-Ground Biomass Estimation in Tropical Forest of Royal Chitwan National Park (M. Sc. thesis). Central Department of Botany, Kirtipur, Kathmandu.

[38] Shrestha, B. M., \& Singh, B. R. (2008). Soil and vegetation carbon pools in a mountainous watershed of Nepal. Nutrient Cycling in Agroecosystems, 81(2), 179-191.

[39] Shrestha, B. P. (2008). An analytical study of carbon sequestration in three different forest types of mid hills of Nepal. Tribhuwan University, Institute of Forestry, Pokhara.

[40] Timilsina, N., Ross, M. S., \& Heinen, J. T. (2007). A community analysis of sal (Shorea robusta) forests in the western Terai of Nepal. Forest Ecology and Management, 241(1-3), 223-234.

[41] Webb, E. L., \& Sah, R. N. (2003). Structure and diversity of natural and managed sal (Shorea robusta Gaertn. f.) forest in the Terai of Nepal. Forest Ecology and Management, 176(1-3), 337-353.

[42] Walkley, A. E. \& J. A. Black. 1958. An Examination of the Method for Determining Soil Organic Method, and Proposed Modification of the Chromic Acid Titration Method. Soil Science 37: 29-38.

Citation: Ram Asheshwar Mandal, et.al, "Comparison Growing Stock, Carbon Stock and Biodiversity in and Around Banke National Park, Nepal”. International Journal of Advanced Research in Botany (IJARB), vol. 5, no. 4, pp. 1-9, 2019. DOI: http://dx.doi.org/10.20431/2455-4316.0504001.

Copyright: (C) 2019 Authors. This is an open-access article distributed under the terms of the Creative Commons Attribution License, which permits unrestricted use, distribution, and reproduction in any medium, provided the original author and source are credited. 